\title{
ON THE INCIDENCE OF CONGENITAL HYPERTROPHIC PYLORIC STENOSIS IN THE 17th AND 18th CENTURIES
}

BY

\author{
C. E. KELLETT, M.D., M.R.C.P.,
}

(From the University of Durham College of Medicine, and the Babies'

Hospital, Newcastle-on-Tyne.)

The clinical picture presented by hypertrophic pyloric stenosis in the child is so distinctive that it seems improbable that such a condition, had it been as common as it is now, should have failed to attract attention before Hirschsprung's ${ }^{1}$ presentation of two cases in 1888. There has been, therefore, on the one hand, a tendency, initiated by Osler $^{2}$ in 1903 with his reprint of the case reported by Beardsley ${ }^{3}$ in $\mathbf{1 7 8 8}$, to search the literature for earlier descriptions of the condition; and on the other hand room, possibly, for speculation whether any change in the modern mode of life could have favoured the development of this condition, the rtiology of which is unknown.

During the past six years three isolated and earlier examples of this condition have been recovered; Foot $e^{4}$ has called attention to the case described by Armstrong ${ }^{5}$ in 1771, Still ${ }^{6}$ to that by Weber ${ }^{7}$ in 1758, and Caulfield $^{8}$ to that described by Blair ${ }^{9}$ in 1717 .

Recorded by Patrick Blair' (1717). A male infant who at ' a month old was seized with a violent vomiting and a stoppage of urine and stool. Some time after both these became more regular, but the vomiting still continued.' He died at 5 months, very emaciated and weighing no more than $5 \mathrm{lb}$. Post mortem 'the ventriculus was more like to an intestine than a stomach, its length being 5 inches and its breadth but one inch ... The pylorus and almost half the duodenum were cartilaginous and something inclined to an ossification.'

Recorded by Christopher Weber' (1758). Female, newly born infant. 'Sucked milk without difficulty but soon after she had filled her stomach with this infant nourishment she returned it by vomiting.' She died on the 6th day. Post mortem 'the pylorus was hard to touch like cartilage, and contracted. On incision its substance was seen to be thick, and the tightness of its contraction made the lumen similar.'

Recorded by George Armstrong ${ }^{5}$ (1771). An infant, sex not stated, suffered from ' watery gripes,' and died at about 3 weeks old. Post mortem ' $I$ found most of the stomach ... in the same tender state, but towards the pylorus the structure was firm enough as likewise that of the intestine ... the stomach was quite distended with curdled milk and victuals ... but the whole intestines were remarkably empty ... it looked as if the disease had been chiefly owing to a spasm in the pylorus.'

Recorded by Hezekiah Beardsley ${ }^{3}$ (1788). A male infant showed from the first week 'puking . . . of the milk and of every other substance almost instantaneously ... The feces were small in quantity . . . yet seemed otherwise pretty well ... yet more lean.' He died at the age of about 5 years. The account of the necropsy contains the following:- 'The esophagus was found greatly distended ... from one end to the other of this tube, between the circular fibres which compose the middle 
coat were small vesicles, some of which contained a table-spoonful of a thin fluid like water, and seemed capable of holding much more. I next examined the stomach, which was unusually large ... it contained about a wine pint of fluid exactly resembling that found in the vesicles ... The pylorus was invested with a hard compact substance, or schirrosity, which so completely obstructed the passage into the duodenum, as to admit with the greatest difficulty the finest fluid ... '

As a rule, once a new condition has been described, fresh examples quickly follow, and since this did not occur, it might, therefore, be argued that during the eighteenth century this condition must have been exceedingly rare. A consideration of the above records suggests that such a deduction cannot reasonably be made, for, with the exception possibly of George Armstrong, whose case bears little resemblance to one of pyloric stenosis, these cases have been reported by people of little or no eminence, in journals of small circulation in the medical world, and may well have failed to attract notice. It is, moreover, remarkable that, with the exception of Weber's case, each autopsy (and, in every case, the diagnosis appears to have been made at autopsy), presents certain anomalous features that contrast with the general uniformity of the findings of the more recent cases.

Though the following case of vomiting ascribed to pyloric stenosis is advanced with considerable diffidence, for the child recovered under treatment and there could be no post-mortem confirmation, it has this interest, that it occurred in the practice of one of the foremost clinicians of the period concerned, was recorded at length in a book widely read by his contemporaries and juniors, and as we shall show excited a certain amount of attention; this case is moreover almost a hundred years prior to any hitherto described.

Fabricius Hildanus ${ }^{10}$ was born in 1560 and died in 1634, ' full of honors and greatly beloved by all who knew him,' having practised medicine in Cologne, in Geneva, Lausanne and Berne. Dezeimeris ${ }^{11}$, who gives a list of all the chapter headings of his concilia, regarded him as the restorer of German surgery, and his works as being even then, in 1828, a fecund source of instruction. They were translated into French in 1669, and his collected works went through at least four editions in $1646,1652,1652$, and 1682 . In addition to monographs on dysentery, lithotomy, gangrene, and on the ' Conservation of Health,' he published from time to time six 'centuries' of clinical observations, embodied not infrequently in personal letters to his colleagues scattered throughout Europe. After his death a further seventh ' century' was compiled from his and their correspondence. Smallpox and the plague appear frequently in these letters, and also cases of hydrocephaly, one being artificially contrived for the sake of begging, and many interesting cases. In a letter to Horstius brief details are given of one of the earliest cases of fœetal variola (C. IV, Obs. lv., p. 328), and in the very next observation an account of fœtal measles, while his descriptions of certain complications of smallpox in childhood, recorded ' quia non vulgare,' would seem still to be of considerable interest. In Hirsch' ${ }^{12}$ estimation his is the first clear description of cancrum oris or noma-in his first ' century' published in 1611 (Obs. xxx, p. 28) he gives four examples of this rare condition, all in children under the age of five-and he was one of the first of 
his contemporaries to recognize and describe the condition now known as diphtheria (C. III, Obs. x, p. 192).

The following case he recorded under the heading of 'Observatio singularis de obstructione pylori.' It is taken from an observation (C. VI, Obs. xxxiv, p. 541) dealing with dangerous obstructions to the orifices of the stomach.

The lower orifice of the stomach, or pylorus, is rarely obstructed: for it is a little larger than the upper one, hence that which passes through the upper is easily thrust through the lower. Moreover the upper orifice is much exposed to the fluxes down from the head and also to the heated vapours that ascend in the acute diseases, the lower orifice is not so exposed; for all of which reasons it has only once been my fortune to witness this type of obstruction.

This was in 1627 in a small and wasted six months old child, the eldest son of Henry Otho, Esq. This child's stomach had been for several days crammed by his nurse or mother with a thick and viscid pultaceous feed, and its innate heat had proved unequal to the task of digesting this pap sufficiently for it to admit of being passed on to the intestine at the right time. Gradually the pap became packed in the stomach to such an extent that the pylorus became obstructed so that all the child swallowed he vomited up again and nothing passed through his bowel. Owing to this, the little child became so weak that those in attendance considered him to be at any moment on the point of giving up the ghost. It was at this juncture that I was called in, and by the divine grace had the good fortune to cure the child.

I will let you have the details of the remedies by which this was achieved but would first inform you how our people prepare the pap and how they cram it into their children.

They boil very pure farina of wheat or of spelt together with whole milk in a vessel until it goes into a thick and viscid pap; and in this as a rule they also mix some butter. Then the nurse or mother places the child supine on its back and with her right index finger takes up some of the pap and thrusts it into the mouth of the child; frequently, particularly when the child resists her, she thrusts it in as far as the fauces, so that willy nilly the child is forced to swallow the portion.

From this there often arises the very gravest symptoms, the still delicate stomach of the child being loaded with inspissated pap. For the stomach of these children indeed no longer receives what it desires but what the nurse thrusts into it by force. It is however obvious, is it not, if we are to make this point clearly comprehensible that we must first of all consider the mechanism of deglutition, whether it is reflex (' naturalis') or actually voluntary (' animalis'), and dependent on our volition.

There are some who maintain that deglutition is a reflex and others that it is a voluntary act; actually there is some truth in both modes of thought. For the act of mastication in the mouth, and subsequent propulsion on to the esophagus is voluntary and dependent on our volition; while the actual descent down the œsophagus of the food from the mouth, which is carried out by the straight fibres (' fibris rectis') is reflex. And so, so long as the appetite for food is present, so long as in the first place the food has been sent to the œsophagus by voluntary action, the œsophagus by means of its straight fibres draws the food to itself and despatches it on to the stomach. When the appetite fails the attractive power of the osophagus also fails, so much so that if food is offered it does not attract it but spues it out. Should however the nurse, as many of our people are in the habit of doing, thrust the food right down as far as the œsophagus, then the voluntary mechanism is placed out of court, the automatic action of the osophagus comes into play, and in the way I have described will continue to gulp down the food to the point of disrupting the stomach, and this not without considerable danger, as in the case of our patient, to the child. In order to avoid this danger the food should be presented to the child and ingested by him from a spoon (' cochleare'). For by this method 
so long as the natural appetite is present the voluntary mechanism will perform its function and convey the food on to the osophagus, but when the stomach is satisfied the child will forthwith, before the pap reaches the osophagus, spit it out.

I have wanted to make a note of these facts for the sake of nurses, and now in a few words will tell you how I set about obtaining a cure.

First of all I forbade the use of pap, or of other food prepared from bread or cooked farina and prescribed meat extracts only with which I mingled a small quantity of oil of sweet almonds.

In so far as there was very marked obstruction of the pap retained, I ordered inunctions of the hypogastric region of the abdomen with the following oils :-

R.

Ol. amygdalarum dulcium,

$\begin{array}{lllll}\text { Liliorum alborum ana } & \ldots & 3^{j} \\ \text { Ol. ex floribus } & \cdots & \cdots & \sum_{3}^{j} s \\ & & & \text { misce. }\end{array}$

and also had the following emollient quilt ('sacculus,' see Paré, Book xxvi, c. xxxix, p. 655), boiled in water applied hot to the hypogastrium :-

R.

Radicum althex

Liliorum alborum ana $\ldots \quad . \overline{5} \int s$

Malvæ ana $\quad \ldots \quad \ldots \quad m . i$

Absynthii pontici

Florum meliloti ana $\quad \ldots \quad m / s$

Seminis lini,

Fœni græci,

Anisi an

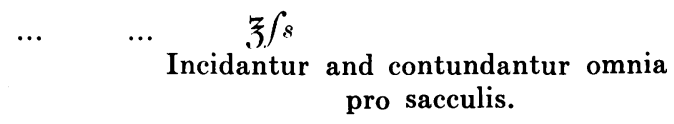

Since he was vomiting up everything given by the mouth and was passing nothing through the lower passages, I prescribed one or two nutrient enemata for every day, made from broth to which was added the yolk of an egg and a small quantity of mixed sugars. By the use of enemata the child was kept nourished for many days during the whole of which time he vomited up straightway whatever he was given by the mouth. By means of these remedies the child was fortunately restored to life and at the time of writing these notes, 2nd December, 1629, is alive and perfectly well. Not every obstruction, therefore, of the lower orifice of the stomach is to be considered incurable.

It could be very reasonably argued that this case represented simply an example of indigestion following over-feeding occurring in the practice of a surgeon knowing little of children; but this would not, I think, be quite fair, for a large proportion of the large practice of Hildanus appears to have been with children.

In 1618, when the smallpox was current in Basle, he states that with his own eyes he saw over 500 children die of the condition, and adds significantly that ' of those that survived not a few were left blind,' (C. VI, Obs. xiv, p. 509), and over eighty of his six ' centuries' of remarkable cases are concerned with children under the age of fifteen.

His statement that this was the only case of this nature that he had encountered is not, therefore, one that should be lightly discounted, and one that he rarely makes, but, it is interesting to note, he makes it again in connection with a case (C. V, Obs. liii, p. 142) apparently of diabetes insipidus, in a boy of seven. He points out that Galen ${ }^{13}$ himself only met with two 
examples of the condition and that it was one which he ' had only one occasion to note in the whole of the time he had spent in practice as a physician and surgeon.' This boy's thirst was such that each night he drank over $4,500 \mathrm{c.cm}$. of water-' plusquam decem libras '-not including the wine he mixed with it, and straightway voided it as urine. Still ${ }^{14}$, who in 1924 had notes of 249 cases of pyloric stenosis, mentions only one case of diabetes insipidus, and John Thomson ${ }^{15}$ in his text-book only two.

Whether or not Hildanus had described a case which really was one of hypertrophic pyloris stenosis (and it is singularly unfortunate that he gives us no clue when the condition started, other than that the child was apparently very wasted when he was called in at six months, and no definite indication as to how long recovery took), such a case report under such a heading would, one imagines, if sufficiently widely reported, focus the attention of clinicians on such cases of intractable vomiting and constipation in early infancy as they should happen to encounter in their practice.

But, while fresh examples of noma and of 'catarrhus suffocativus' rapidly arose, $I$ have been unable to find any other example of vomiting in infancy, thought to be due to pyloric obstruction, in the rather limited number of text-books of this period to which $I$ have had access; and this, though there was ample evidence that the writings of Hildanus were not neglected. He is, perhaps, the most frequently quoted, as well as one of the most esteemed, authors of his time.

Wolfgang Hoefer ${ }^{16}$ refers to this case, in the section of his ' Hercules Medicus' devoted to children, in a paragraph headed pyloric obstruction. He gives a complete summary of it, declares it to be ' an affection in itself rare, and so hard of diagnosis,' and does not himself appear to have met with an example of the condition, though he was a clinician of considerable experience and incidentally one of the first to describe cretinism in Styria. This book of his went through at least three editions.

The two great 17th century collections of remarkable clinical cases of Forestus and of Schenkius, ' author of one of the most useful works that were published in medicine in the 16th century,' were both completed and published before this sixth ' century' of Hildanus was published in 1641; but by 1665 references appear in editions of Schenkius ${ }^{17}$ under the chapter devoted to affections of the pylorus calling attention to this case, which appears to have continued to arouse interest and comment throughout the next sixty years or so.

Both Dolaeus $^{18}$ in 1688 , and the more renowned Hoffman ${ }^{19}$ in 1740 , however, emphasize the explanation put forward by Hildanus, and treat of it in the subsection of their chapter on pædiatrics particularly concerned with the use and abuse of thickened feeds, rather than in the sections devoted to vomiting in childhood; while the historical method of approach is further confused by the appearance during the eighteenth century of certain smaller books devoted entirely to pædiatrics by Harris, Armstrong, Astruc and Underwood, that are poor in references to former work, do not mention this case of Hildanus, but in two instances do give accounts of post-mortem examinations that suggest this condition. It is disconcerting to find 
that Armstrong's case was associated by him during life with ' watery gripes,' and Underwood's ${ }^{20}$ with a ' recurring blackness or discolouration of the infant.'

A further difficulty is presented by the enormous infant mortality rate of the period. Graunt's ${ }^{21}$ well known figures suggested that ' of a hundred quick conceptions in London thirty-six die before they be six years'; Mallet's ${ }^{22}$ figures for Geneva indicate an even higher rate of infant mortality during the 17th century in Switzerland.

Despite this I have ventured to recall this case, in the belief that it was better calculated to direct attention to clinical examples of hypertrophic pyloric stenosis than any other case published prior to the end of the 19th century; and that its failure to do so is possibly of significance, as is certainly the statement that such a case was only once met with in the practice of a great and busy physician.

\section{Summary.}

Attention is called to a case of pyloric stenosis in infancy published almost a hundred years prior to any previously reported case. While it is by no means certain that this case represents a true example of congenital hypertrophic stenosis in infancy, it is suggested that its publication, which aroused a certain amount of interest, would have sufficed to have directed attention to this condition had it been at all common at that time.

\section{REFERENCES.}

1. Hirschsprung, H., Jahrb. f. Kinderh., Berlin, 1888, XXVIII, 61.

2. Osler, W., Arch. Pediat., N.Y., 1903, XX, 355.

3. Beardsley, H. K., Cases and Observations by the Medical Society of Newhaven, Newhaven, 1788, I, (vide Ruhrah, Am. J. Dis. Child., Chicago, 1930, XL, 146).

4. Foote, J. A., Am. J. Dis. Child., Chicago, 1918, XV, 351.

5. Armstrong, G., An essay on the Diseases most fatal to Infants, London, 1771.

6. Still, G., History of Pædiatrics, Oxford, 1931, 398.

7. Weber, C., Inaug. Thesis, Gottingen, 1758.

8. Caulfield, E., Am. J. Dis. Child., Chicago, 1930, XL, 1069.

9. Blair, P., Philosoph. Trans., Roy. Soc., London, 1717, XXX, No. 353, 631.

10. Hildanus, F., Opera Omnia, Frankfort, Joh. Bejerus, 1646.

11. Dezeimeris, Ollivier, \& Raige-Delorme, Dictionnaire Historique de la Médecine, Paris, Bechet Jeune, 1828, II, 252.

12. Hirsch, Handbook of Geographical and Historical Pathology. New Sydenham Soc., Trans. London, 1886, III, 272 \& 48.

13. Galen, Trans. Ch. Daremberg, Paris, Bailliere, 1856, II, 675.

14. Still, G. F., Common Disorders and Diseases of Childhood, Oxford, 4th Ed., 1924.

15. Thomson, J., Clinical Study and Treatment of Sick Children, Edinburgh, 4th Ed.

16. Hoefer, W., Hercules Medicus, Noriberga, 1675, 429.

17. Schenkius, J., Observationum Medicarum Rariorum, Frankfort, 1665, VII, 351.

18. Dolaeus, J., Encyclopædia Medica, Venice, 1695, 459.

19. Hoffman, F., Opera omnia, Geneva, 1740, III, 474.

20. Underwood, M., A treatise on the Diseases of Children, London, 7th Ed., I, 14 (footnote).

21. Graunt, J., Economic Writings of Sir William Petty, Edited by C. H. Hull, Cambridge, 1899, II, 386.

22. Mallet, E., Ann. d'hyg. pub. et de méd. legale, Paris, 1837, XVII, 30 (quoted by Hull supra.). 